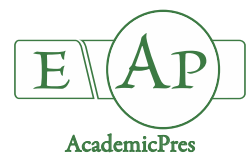

\title{
Chemical Composition of the Essential Oils of Three Ocimum basilicum L. Cultivars from Serbia
}

\author{
Aleksandra S. ILIĆ ${ }^{1 *}$, Mališa P. ANTIĆ ${ }^{2}$, Slavica C. JELAČIĆ², \\ Tatjana M. ŠOLEVIĆ KNUDSEN ${ }^{3}$ \\ ${ }^{1}$ Technical College of Applied Studies, Nemanjina 2, 12000 Požarevac, Serbia; a.ilic.vts@gmail.com ("corresponding author) \\ ${ }^{2}$ University of Belgrade, Faculty of Agriculture, P.O.Box 14, 11080 Belgrade, Serbia; mantic@agrif.bg.ac.rs; jelacic@agrif.bg.ac.rs \\ ${ }^{3}$ University of Belgrade, Institute of Chemistry, Technology and Metallurgy, Njegoševa 12, P.O. Box 473, 11000 Belgrade, \\ Serbia; tsolevic@chem.bg.ac.rs
}

\begin{abstract}
Basil essential oil (BEO) contains a wide range of chemical compounds whose content may vary depending on chemotypes, environmental conditions, agronomic techniques and particularly the origin of the plant. In our present study, essential oils (EOs) were isolated by hydrodistillation method from dry herbs of three basil cultivars and analyzed by GC-FID and GC-MS. Two of the tested cultivars belong to sweet basil group $\left(\mathrm{B}_{1}\right.$ and $\left.\mathrm{B}_{2}\right)$ while the third one was large leafed 'Genovese' basil $\left(\mathrm{B}_{3}\right)$. $\mathrm{EO}$ content in the dry herb was $0.65 \%, 0.41 \%$ and $0.62 \%$ respectively. The main classes of compounds of $\mathrm{B}_{1} \mathrm{EO}$ and $\mathrm{B}_{3} \mathrm{EO}$ were sesquiterpene hydrocarbons $(38.39 \%$ and $37.95 \%)$, oxygenated monoterpenes $(25.44 \%$ and $28.04 \%)$ and phenylpropanoids (17.43\% and $15.71 \%$ ). The main constituents of both EOs were monoterpene alcohol linalool (13.68\% and $15.38 \%)$, phenoyl derivate eugenol (10.83\% and $8.97 \%)$ and sesquiterpene hydrocarbon $\alpha$-bergamotene $(8.12 \%$ and $9.25 \%)$. In both EOs, epi-bicyclosesquiphellandrene was detected in considerable amount $(7.03 \%$ and $8.07 \%)$. The most abundant compound classes in $\mathrm{B}_{2} \mathrm{EO}$ were oxygenated monoterpenes (52.07\%), sesquiterpene hydrocarbons $(24.27 \%)$ and phenylpropanoids (10.95\%). Linalool was the dominant compound (40.97\%), followed by epi-bicyclosesquiphellandrene $(8.70 \%)$ and methyl chavicol (7.92\%). The results showed complex chemical composition of BEOs and pointed out the presence of biologically active compounds of importance for different branches of the pharmaceutical, chemical and food industry. Although there are differences in the chemical composition of the BEOs, the obtained results show that all of the tested cultivars are rich in compounds which are responsible for biological activities.
\end{abstract}

Keywords: basil, essential oil, GC-FID, GC-MS, hydrodistillation

\section{Introduction}

The family Lamiaceae is widely distributed over the world. It comprises over 5,000 medicinal and aromatic plant species whose EOs have multiple applications (Sakkas and Papadopoulou, 2017; Piras et al., 2018). Basil (Ocimum basilicum L.) is a widely known member of Lamiaceae family. At present, this annual aromatic plant, native to Southeast Asia, is globally cultivated and has significant economic value (Varga et al., 2017). Basil has been grown traditionally as a decorative, medicinal, seasoning and ritual herb (Jelačić et al., 2011). Additionally, basil is mostly cultivated for its EO, which has broad pharmaceuticals and industrial uses (Shiwakoti et al., 2017). BEO has been used in the food industry, especially in vegetables, meat and dairy products. It has a been used as a flavouring as well as a natural agent for increasing the shelf life of food products (Riveros et al., 2015; Sharafati-Chaleshtori et al., 2015; Piras et al., 2018). It is also used in commercial fragrances, oral care products and aromatherapy (Labra et al., 2004).

The content and chemical composition of the BEO has been the subject of many studies. The yield from different plant parts varies between $0.2-1.9 \%$ with the main components being linalool, methyl chavicol, eugenol and methyl cinnamate, as well as 1,8-cineole, methyl eugenol, geraniol, geranial, neral and $\alpha$-bergamotene (Marotti et al., 1996; Labra et al., 2004; Sakkas and Papadopoulou, 2017). Based on the distribution and abundances of the main compounds in EO composition, Marotti et al. (1996) described three chemotypes: (1) linalool, (2) linalool / methyl chavicol and (3) linalool/eugenol chemotypes. In recent study which comprised 85 accessions of $O$. basilicum, based on seven major compounds, Varga et al. (2017) 
348

proposed intraspecific characterization into five chemotypes: (A) linalool, (B) linalool/trans- $\alpha$-bergamotene, (C) linalool/methyl chavicol, (D) linalool/trans-methyl cinnamate and (E) methyl chavicol. Chemotypes A and C can be considered to be European chemotypes. Chemotype $\mathrm{D}$ is a Tropical chemotype, while Chemotype $\mathrm{E}$ is described as a Reunion chemotype (Varga et al., 2017). The composition of BEO is highly dependent on the chemotype, phenological stage of the plant as well as on other factors (growing and agroclimatic conditions, drying and distillation method) and thus also affects the biological activites (Marotti et al., 1996; Klimánková et al., 2008; Taie et al., 2010; Wesolowska et al., 2012; Shiwakoti et al., 2017).

BEOs have been reported to possess numerous biological properties. A number of authors have mentioned antioxidant (Juliani and Simon, 2002; Božin et al., 2006; Taie et al., 2010; Beatović et al., 2013; Shirazi et al., 2014; Riveros et al., 2015; Sharafati-Chaleshtori et al., 2015; Elgndi et al., 2017; Shiwakoti et al., 2017; Stanojević et al., 2017), antimicrobial (Božin et al., 2006; Carović-Stanko et al., 2010; Soković et al., 2010; Beatović et al., 2013; Stefan et al., 2013; Joshi, 2014; Shirazi et al., 2014; SharafatiChaleshtori et al., 2015; Silva et al., 2015; Chauhan et al., 2017; Sakkas and Papadopoulou, 2017; Stanojević et al., 2017; Piras et al., 2018), anticancer (Taie et al., 2010; Shirazi et al., 2014; Elgndi et al., 2017) and insect-repelling properties (Perumalsamy et al., 2014) of BEO due to its phenolic and aromatic constituents.

The content and composition of EO are very important parameters for assessing the quality of basil and its application as raw material for different branches of pharmaceutical, food and chemical industries (Jelačić et al., 2011). Therefore, the aim of the present study was to investigate the chemical constituents of the BEOs from three cultivars planted in the Republic of Serbia.

\section{Materials and Methods}

Plant material

Dried basil herb $\mathrm{B}_{1}$ was obtained from "Bilje Borča" Belgrade while $\mathrm{B}_{2}$ material was obtained from Institute for Medicinal Plant Research "Dr Josif Pančić" Belgrade in 2016. The materials were identified and representative herbarium specimens were deposited at "Bilje Borča" (serial No. L018-05-15) and the Institute for Medicinal Plant Research "Dr Josif Pančić" (serial No. 02740216). The $B_{3}$ material was 'Genovese' basil from the collection of the Institute for Crop Sciences of the Faculty of Agriculture in Belgrade and the Plant Gene Bank of Serbia where it is deposited under DB code (DB-01).

\section{Isolation of the essential oils}

The plant material was milled in a laboratory electric mill immediately before extraction and $20 \mathrm{~g}$ was subjected to hydrodistillation for $2 \mathrm{~h}$ using a Clevenger type apparatus according to the procedure IV of the Yugoslavian Pharmacopoeia (1984). The EOs were dried over anhydrous sodium sulphate and stored in sealed vials at $4^{\circ} \mathrm{C}$ until further analysis. The yield of EO was calculated based on dry weight of plant material and expressed as \% (mL $\mathrm{EO} / 100 \mathrm{~g}$ of dry plant material).

\section{Essential oil analysis}

Qualitative and quantitative analysis was carried out using GC-FID and GC-MS. For GC-MS analyses, an Agilent $7890 \mathrm{~N}$ gas chromatograph with a HP5-MS capillary column (30 m length; $0.25 \mathrm{~mm}$ inner diameter; $0.25 \mu \mathrm{m}$ film) was used. The following temperature program was employed: $60{ }^{\circ} \mathrm{C}$ for $0 \mathrm{~min}$; then $3{ }^{\circ} \mathrm{C} \mathrm{min}^{-1}$ to $280^{\circ} \mathrm{C}$ and then held for $20 \mathrm{~min}$. Helium was used as the carrier gas with the flow rate $1 \mathrm{~mL} \mathrm{~min}^{-1}$. The $\mathrm{GC}$ was coupled to a Hewlett-Packard 5972 MSD operated at $70 \mathrm{eV}$ and scanning masses in the 40-550 range. The peaks were identified by comparison of their retention indices (calculated relative to n-alkanes) to the literature data (Adams, 2007; Babushok et al., 2011), and by comparison of their mass spectra to the mass spectra in the databases (NIST/EPA/NIH mass spectral library NIST2000, Wiley/NBS registry of mass spectral data, 7 th ed., electronic versions).

For GC-FID analyses, an Agilent 4890A gas chromatograph with a HP5-MS capillary column $(30 \mathrm{~m}$ length; $0.25 \mathrm{~mm}$ inner diameter; $0.25 \mu \mathrm{m}$ film) was used. The temperature program employed was the same as the one used for GC-MS analyses. Hydrogen was used as carrier gas $\left(1 \mathrm{~mL} \mathrm{~min} \mathrm{~m}^{-1}\right)$. The GC was coupled to a FID detector operating at $300^{\circ} \mathrm{C}$.

\section{Statistical analysis}

The analysis of variance (ANOVA) was carried out using a significance level of $\mathrm{p} \leq 0.05$. The least significant difference (LSD) test, if necessary, was used to determine the significant differences between tested basil cultivars.

\section{Results}

\section{The yield of BEOs}

All cultivars analyzed in the present research yielded light yellow EOs. The contents of $\mathrm{B}_{1} \mathrm{EO}, \mathrm{B}_{2} \mathrm{EO}$ and $\mathrm{B}_{3} \mathrm{EO}$ were $0.65 \%(0.65 \mathrm{~mL} \mathrm{EO} / 100 \mathrm{~g}$ of dry plant material), $0.41 \%$ and $0.62 \%$ respectively. Comparing the obtained yields of BEO using LSD test, it can be concluded that there is a statistically significant difference between the observed cultivars in their content of the EOs.

Content of EO in basil was investigated by different authors. Jelačić et al. (2011) found that the yield of EO from aerial parts of 10 tested basil populations varied from $0.87 \%$ to $1.84 \%$. Božin et al. (2006) and Elgndi et al. (2017) reported the yield of BEO from Serbia to be $0.37 \%$ and $0.67 \%$, respectively. Beatović et al. (2015) reported the yield of EO from twelve Ocimum species varied from $0.65 \%$ to $1.90 \%$. Literature data of Romanian basil cultivars show the EO level from $0.2 \%$ to $0.6 \%$ (Benedec et al., 2009). The yield of obtained BEO in Republika Srpska (Bosnia and Herzegovina) was $0.4 \%$ (Stanojević et al., 2017). A study by Wesolowska et al. (2012) showed that the content of EO in herbs of three tested basil cultivars ranged from $0.38 \%$ to $0.55 \%$. Content of the $\mathrm{EO}$ of basil cultivars from Albania was ranged from $0.11 \%$ to $3.40 \%$, while content of the EO obtained from aerial parts of 10 Italian basil cultivars was in the range from $0.3 \%$ to $0.8 \%$ (Marotti et al., 1996; Cheliku et al., 2015).

It can be concluded that the content of BEO 
determined in our present research is in good agreement with the literature data.

Chemical composition of $B E O$ s

The chemical composition of examined BEOs is presented in Table 1. Overall, 60 volatile constituents in the three BEOs were identified: 38 in $\mathrm{B}_{1} \mathrm{EO}$ (94.99\% of the total oil), 42 in $\mathrm{B}_{2} \mathrm{EO}$ (90.85\% of the total oil) and 30 compounds in $\mathrm{B}_{3} \mathrm{EO}$ ( $95.45 \%$ of the total oil). Statistical analysis of the results obtained by GC-MS analysis was conducted for all constituents with the content higher than $1 \%$ of the EO.

Table 1. Chemical composition of Ocimum basilicum L. essential oils from three tested cultivars

\begin{tabular}{|c|c|c|c|c|c|}
\hline \multirow{2}{*}{ Compound } & \multicolumn{3}{|c|}{ Content (\%) } & \multirow{2}{*}{$\mathrm{RI}^{\mathrm{a}}$} & \multirow{2}{*}{$\mathrm{RI}^{\mathrm{b}}$} \\
\hline & $\mathrm{B}_{1} \mathrm{EO}$ & $\mathrm{B}_{2} \mathrm{EO}$ & $\mathrm{B}_{3} \mathrm{EO}$ & & \\
\hline$\alpha$-Pinene & 1.07 & 0.07 & 1.95 & 939 & 943 \\
\hline Camphene & - & 0.45 & - & 954 & 957 \\
\hline Benzaldehyde & - & 0.02 & - & 961 & 963 \\
\hline$\beta$-Pinene & 2.90 & 0.45 & 2.18 & 980 & 982 \\
\hline 2-Carene & $\cdot$ & 0.06 & - & 1001 & 1005 \\
\hline p-Cymene & - & 0.02 & - & 1026 & 1024 \\
\hline$\beta$-Phellandrene & 1.56 & - & 3.49 & 1030 & 1028 \\
\hline Eucalyptol (1,8-cineole) & 5.98 & 2.12 & 6.20 & 1034 & 1033 \\
\hline cis- $\beta$-Ocimene & - & 0.23 & - & 1039 & 1043 \\
\hline trans- $\beta$-Ocimene & - & 0.02 & - & 1050 & 1051 \\
\hline$\gamma$-Terpinene & 0.20 & 0.04 & - & 1060 & 1064 \\
\hline trans-Linalool oxide & - & 0.99 & - & 1083 & 1085 \\
\hline Linalool & 13.68 & 40.97 & 15.38 & 1099 & 1103 \\
\hline Camphor & 1.15 & 0.53 & 1.63 & 1144 & 1147 \\
\hline Menthone & 0.19 & - & - & 1154 & 1152 \\
\hline Isomenthone & - & 0.16 & - & 1164 & 1161 \\
\hline Borneol & - & 0.28 & 1.59 & 1165 & 1163 \\
\hline$\delta$-Terpineol & 1.16 & - & - & 1166 & 1167 \\
\hline Menthol & - & 0.15 & - & 1169 & 1170 \\
\hline$\alpha$-Terpineol & 0.91 & 0.48 & - & 1190 & 1189 \\
\hline Estragole (methyl chavicol) & 4.13 & 7.92 & 5.26 & 1196 & 1194 \\
\hline Ethyl octanoate & 0.40 & - & 0.61 & 1196 & 1199 \\
\hline Carvone & 0.15 & 0.89 & 0.14 & 1242 & 1245 \\
\hline Geraniol & 0.49 & 4.80 & 0.11 & 1258 & 1254 \\
\hline Geranial & - & 0.13 & - & 1270 & 1268 \\
\hline Isobornyl acetate & 1.73 & - & 2.91 & 1286 & 1289 \\
\hline Thymol & 0.34 & 0.16 & - & 1302 & 1300 \\
\hline trans-Anethole & - & 1.54 & - & 1301 & 1305 \\
\hline Myrtenyl acetate & - & - & 0.08 & 1327 & 1325 \\
\hline 1,5,5-Trimethyl-6-methylene- cyclohexene & 0.13 & - & - & 1338 & 1335 \\
\hline$\alpha$-Cubebene & 0.75 & 0.08 & 2.61 & 1351 & 1350 \\
\hline Eugenol & 10.83 & 0.62 & 8.97 & 1357 & 1352 \\
\hline Geraniol acetate & $\cdot$ & 0.57 & $\cdot$ & 1386 & 1390 \\
\hline$\beta$-Cubebene & 4.76 & - & - & 1388 & 1388 \\
\hline$\beta$-Elemene & 4.01 & 2.63 & 4.47 & 1391 & 1390 \\
\hline Methyleugenol & 2.13 & 0.69 & 1.48 & 1410 & 1406 \\
\hline$\beta$-Caryophyllene & - & 0.22 & - & 1423 & 1426 \\
\hline$\alpha$-Bergamotene & 8.12 & 1.95 & 9.25 & 1433 & 1430 \\
\hline$\beta$-Copaene & 1.25 & - & 3.92 & 1433 & 1435 \\
\hline cis- $\beta$-Farnesene & 0.67 & - & 1.10 & 1444 & 1447 \\
\hline$\alpha$-Humulene & 1.40 & 0.78 & 1.36 & 1456 & 1460 \\
\hline$\gamma$-Gurjunene & - & - & 1.05 & 1479 & 1478 \\
\hline D-Germacrene & - & 3.42 & - & 1480 & 1483 \\
\hline Epi-bicyclosesquiphellandrene & 7.03 & 8.70 & 8.07 & 1488 & 1487 \\
\hline$\beta$-Guaiene & 2.34 & - & - & 1489 & 1490 \\
\hline$\alpha$-Selinene & - & 0.72 & - & 1494 & 1492 \\
\hline Bicyclogermacrene & 1.85 & 0.86 & - & 1495 & 1495 \\
\hline$\alpha$-Muurolene & - & 3.41 & - & 1497 & 1498 \\
\hline$\gamma$-Muurolene & 3.71 & - & 0.54 & 1474 & 1476 \\
\hline Bulnesene & - & 1.58 & 5.58 & 1505 & 1502 \\
\hline cis-Calamenene & 2.50 & - & - & 1521 & 1520 \\
\hline cis-Nerolidol & 0.52 & - & - & 1535 & 1538 \\
\hline Spathulenol & 3.70 & 0.68 & 2.25 & 1577 & 1580 \\
\hline Caryophyllene oxide & 0.37 & - & - & 1582 & 1586 \\
\hline$\alpha$-Cadinol & 1.41 & 0.87 & - & 1632 & 1637 \\
\hline$\beta$-Eudesmol & - & 0.43 & - & 1648 & 1649 \\
\hline$\alpha$-Bisabolol & - & - & 2.10 & 1685 & 1681 \\
\hline Hexahydrofarnesyl acetone & 0.29 & 0.13 & 0.48 & 1836 & 1833 \\
\hline Phytol & 0.98 & 0.11 & 0.62 & 2122 & 2120 \\
\hline Phytol-acetate & 0.20 & - & 0.07 & 2225 & 2229 \\
\hline Total identified (\%) & 94.99 & 90.85 & 95.45 & & 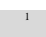 \\
\hline
\end{tabular}

$\because$ compound not detected

$\mathrm{RI}^{\mathrm{a}}$ - Relative retention indices on a column with dimethylsilicone stationary phase with 5\% phenyl groups reported in literature (Adams, 2007; Babushok et al., 2011;

NIST database, electronic version).

$\mathrm{RI}^{\mathrm{b}}$ - Relative retention indices experimentally determined and calculated against n-alkanes (C8-C32) on the HP-5MS column. 
350

Based on statistical analysis of the selected constituents, it can be concluded that there were no statistically significant differences between the examined BEOs.

The main classes of compounds of all the examined BEOs were sesquiterpene hydrocarbons $(38.39 \%, 24.27 \%$ and $37.95 \%)$, oxygenated monoterpenes $(25.44 \%, 52.07 \%$ and $28.04 \%)$ and phenylpropanoids $(17.43 \%, 10.93 \%$ and 15.71\%). Monoterpene hydrocarbons and oxygenated sesquiterpenes were present in low amounts in all the analyzed BEOs $(<10 \%)$. The relative abundances of the main classes of compounds are shown in Table 2.

The main constituent of all BEOs was monoterpene alcohol linalool (13.68\%, 40.97\% and 15.38\%). In considerable amounts in $\mathrm{B}_{1} \mathrm{EO}$ and $\mathrm{B}_{3} \mathrm{EO}$ the following constituents were detected: eugenol (10.83\% and $8.97 \%), \alpha$ bergamotene $(8.12 \%$ and 9.25\%), epibicyclosesquiphellandrene (7.03\% and $8.07 \%)$, eucalyptol $(5.98 \%$ and $6.20 \%)$ and methyl chavicol $(4.13 \%$ and 5.26\%). Except from linalool, compounds with higher abundance in $\mathrm{B}_{2} \mathrm{EO}$ were epi-bicyclosesquiphellandrene (8.70\%), methyl chavicol (7.92\%), geraniol $(4.80 \%)$, Dgermacrene (3.42\%) and $\alpha$-muurolene (3.41\%).

As $\mathrm{B}_{1} \mathrm{EO}$ and $\mathrm{B}_{3} \mathrm{EO}$ showed similarity in chemical composition, the major difference between these BEOs and $\mathrm{B}_{2} \mathrm{EO}$ was in the content of eugenol. $\mathrm{B}_{2} \mathrm{EO}$ had the lowest content of this phenoyl derivate $(0.62 \%)$ in which the two other cultivars were rich (10.83\% and $8.97 \%)$. Politeo et al. (2007) found that the antioxidant activity of BEO highly depends on the content of this compound. Accordingly, it can be expected that EOs from these two basil cultivars will be more effective antioxidants compared to $\mathrm{B}_{2} \mathrm{EO}$. Furthermore, $\mathrm{B}_{1} \mathrm{EO}$ and $\mathrm{B}_{3} \mathrm{EO}$ had higher concentration of eucalyptol $(5.98 \%$ and $6.20 \%)$ relative to $\mathrm{B}_{2} \mathrm{EO}(2.12 \%)$. Monoterpene alcohol geraniol was present in considerable amount in $\mathrm{B}_{2} \mathrm{EO}(4.80 \%)$ while in two other EOs it was in trace. $\mathrm{D}$-germacrene and $\alpha$-muurolene were sesquiterpene hydrocarbons identified only in $\mathrm{B}_{2} \mathrm{EO}$ while $\beta$-cubebene was identified in significant amount in $\mathrm{B}_{1} \mathrm{EO}$ and it was absent in EOs of other investigated cultivars.

The differences in the chemical composition of the EOs analyzed can be explained as a consequence of differences in growing and agroclimatic conditions.

Many studies reported linalool as the main compound of investigated BEOs (Marotti et al., 1996; Juliani and Simon, 2002; Wesołowska et al., 2012; Cheliku et al., 2015; Riveros et al., 2015; Silva et al., 2015; Elgndi et al., 2017). In study of Beatović et al. (2015), which included twelve basil cultivars, the oxigenated monoterpenes were predominant in eight cultivars with linalool as the main constituent. Shirazi et al. (2014) and Sharafati-Chaleshtori et al. (2015) reported methyl chavicol as the main compound of BEO while eugenol was detected as compound with highest abundance by Piras et al. (2018). Presence of the sesquiterpene hydrocarbon epi-bicyclosesquiephellandrene as a compound with higher abundance is comparable with investigation of Benedec et al. (2009). The chemical composition of BEO 'Genovese' has been well described in the literature and the composition and abudances of major components in our study is in accordance with earlier studies (Marotti et al., 1996; Juliani and Simon, 2002; Labra et al., 2004; Carović-Stanko et al., 2010; Beatović et al., 2013; Stefan et al., 2013).
It can be concluded that the compositions of the BEOs investigated in our present research are in good agreement with the literature data.

Table 2. The relative abundances of the main classes of compounds in tested $\mathrm{BEO}$

\begin{tabular}{cccc}
\hline Classes of compounds & \multicolumn{3}{c}{ Content $(\%)$} \\
\cline { 2 - 4 } & $\mathrm{B}_{1} \mathrm{EO}$ & $\mathrm{B}_{2} \mathrm{EO}$ & $\mathrm{B}_{3} \mathrm{EO}$ \\
\hline Monoterpene hydrocarbons & 5.73 & 1.34 & 7.62 \\
Oxygenated monoterpenes & 25.44 & 52.07 & 28.04 \\
Phenylpropanoids & 17.43 & 10.93 & 15.71 \\
Sesquiterpene hydrocarbons & 38.39 & 24.27 & 37.95 \\
Oxygenated sesquiterpenes & 6.00 & 1.98 & 4.35 \\
Diterpenes & 1.18 & 0.11 & 0.69 \\
Other & 0.82 & 0.15 & 1.09 \\
\hline
\end{tabular}

\section{Conclusions}

In this study, the chemical composition of the EOs from three basil cultivars from Serbia was investigated. The contents of BEOs were in good agreement with the literature data. The statistical analysis demonstrated a statistically significant difference between the observed cultivars in their contents of the EOs.

It was concluded that the compositions of the BEOs investigated were in good agreement with the literature data. Some differences in abundances and distribution of their constituents were observed. However, the statistical analysis of the selected constituents did not reveal any statistically significant differences between the examined BEOs. The differences in the chemical composition of the EOs analyzed were explained as a consequence of differences in growing and agroclimatic conditions. Although there were differences between the tested BEOs, the obtained results showed that all of them were rich in compounds which are responsible for biological activities. Further studies of examined cultivars are required to determine their biological activities and applicability as food additives.

\section{Acknowledgements}

This research was supported by the Ministry of Education, Science and Technological Development of the Republic of Serbia (Project No 176006). We thank the Institute for Medicinal Plant Research "Dr Josif Pančic" Belgrade and "Bilje Borča" Belgrade for the samples provided for this research.

\section{References}

Adams RP (2007). Identification of essential oil components by gas chromatography/mass spectrometry. Allured Publishing Corporation, 4thed. USA pp 69-351.

Babushok VI, Linstrom PJ, Zenkevich IG (2011). Retention indices for frequently reported compounds of plant essential oils.Journal of Physical and Chemical Reference Data 40:1-47.

Beatović DV, Jelačić SC, Oparnica CDj, Krstić-Milošević DB, Glamočlija JM, Ristić MS, Šiljegović JD (2013). Chemical composition, antioxidative and antimicrobial activity of essential oil of Ocimum sanctum L. Hemijska Industrija 67(3):427-435.

Beatović DV, Krstić-Milošević DB, Trifunović SS, Šljegović JD, Glamočlija 
JM, Ristić MS, Jelačić SC (2015). Chemical composition, antioxidant and antimicrobial activities of the essential oils of twelve Ocimum basilicum L. cultivars grown in Serbia. Records of Natural Products $9(1): 62-75$.

Benedec D, Oniga I, Oprean P, Tamas M (2009). Chemical composition of the essential oils of Ocimum basilicum L. cultivated in Romania. Farmacia 57(5):625-629.

Božin B, Mimica-Dukić N, Simin N, Anckov G (2006). Characterisation of the volatile composition of essential oils of some Lamiaceae spices and the antimicrobial and antioxidant acitivites of the entire oils. Journal of Agricultural and Food Chemistry 54(5):1882-1828.

Carović-Stanko K, Orlić S, Politeo O, Strikić F, Kolak I, Miloš M, Satović Z (2010). Composition and antibacterial activities of essential oils of seven Ocimum taxa. Food Chemistry 119:196-201.

Cheliku N, CvetkovikjKI, Stefkov G, Karapandzova M, Bardhi N, Qjazimi B, Kulevanova S (2015). Essential oil composition of five basil cultivars (Ocimum basilicum) from Albania. Macedonian Pharmaceutical Bulletin 61(2):11-18.

Chouhan S, Sharma K, Guleria S (2017). Antimicrobial activity of some essential oils-Present status and future perspectives. Medicines 4:58-79.

Elgndi MA, Filip S, Pavlić B, Vladić J, Stanojković T, Žižak Ž, Zeković Z (2017). Antioxidative and cytotoxic activity of essential oils and extracts of Satureja montana L., Coriandrum sativum L. and Ocimum basilicum L. obtained by supercritical fluid extraction. Journal of Supercritical Fluids 128:128-137.

Jelačić SC, Beatović DV, Prodanović SA, Tasić SR, Moravčević DjZ, Vujošević AM, Vučković SM (2011). Chemical composition of the essential oil of basil (Ocimum basilicum L. Lamiaceae). Hemijska Industrija 65(4):465-471.

Joshi RK (2014). Chemical composition and antimicrobial activity of the essential oil of Ocimum basilicum L. (sweet basil) from Western Ghats of North West Karnataka, India. Ancient Science of Life 33(3):151-156.

Juliani HR, Simon JE (2002). Antioxidant activity of basil. In: Janick J, Whipkey A (Eds). Trends in new crops and new uses. ASHS Press, Alexandria, VA,pp 575-579.

Klimánková E, Holadová K, Haǰšová J, Čajka T, Poustka J, Koudela M (2008). Aroma profiles of five basil (Ocimum basilicum L.) cultivars grown under conventional and organic conditions. Food Chemistry 107:464 472 .

Labra M, Miele M, Ledda B, Grassi F, Mazzei M, Sala F (2004). Morphological characterisation, essential oil composition and DNA genotyping of Ocimum basilicum L. cultivars. Plant Science 167:725731.

Marotti M, Piccaglia R, Giovanelli E (1996). Differences in essential oil composition of basil (Ocimum basilicum L.) Italian cultivars related to morphological characteristics. Journal of Agricultural and Food Chemistry 44(12):3926-3929.

Perumalsamy H, Kim JY, Kim JR, Hwang KN, Ahn YJ (2014). Toxicity of basil oil constituents and related compounds and the efficacy of spray formulations to Dermatophagoides fariae (Acari: Pyroglyphidae). Journal of Medical Entomology 51(3):650-657.

Piras A, Gonçalves MJ, Alves J, Falconieri D, Porcedda S, Maxia A, Salgueiro
L (2018). Ocimum tenuiflorum L. and Ocimum basilicum L., two spices of Lamiaceae family with bioactive essential oils. Industral Crops and Products 113:89-97.

Politeo O, Jukić M, Miloš M (2007). Chemical composition and antioxidant capacity of free volatile aglycones from basil (Ocimum basilicum L.) compared with its essential oil. Food Chemistry 101:379385.

Riveros CG, Nepote V, Grossa NR (2015). Thyme and basil essential oils included in edible coating as a natural preserving method of oilseed kernels. Journal of the Science of Food and Agriculture 96(1):183-191.

Sakkas H, Papadopoulou C (2017). Antimicrobial activity of basil, oregano and thyme essential oil. Journal of Microbiology and Biotechnology 27(3):429-438.

Sharafari-Chaleshtori R, Rokni N, Rafieian-Kapaei M, Drees F, Salehi E (2015). Antioxidant and antibacterial activity of basil (Ocimum basilicum $\mathrm{L}$.) essential oil in beef burger. Journal of Agricultural Science and Technology 17(3):817-826.

Shirazi MT, Gholami H, Kavoosi G, Rawshan V, Tafsiry A (2014). Chemical composition, antioxidant, antimicrobial and cytotoxic activities of Tagetes minuta and Ocimum basilicum essential oils. Food Science and Nutrition 2(2):146-155.

Shiwakoti S, Saleh O, Poudyal S, Barka A, Qian Y, Zheljazkov VD (2017). Yield, composition and antioxidant capacity of the essential oil of sweet basil and holy basil as influenced by distillation method. Chemistry and Biodiversity 14(4):e1600417.

Silva VA, Sousa JP, Guerra FQS, Pessôa HLF, Frietas AFR, Alves LBN, LimaEO (2015). Antibacterial activity of Ocimum basilicum essential oil and linalool on bacterial isolates of clinical importance. International Journal of Pharmacognosy and Phytochemical Research 7:1066-1071.

Soković M, Glamočlija J, Marin PD, Brkić D, van Griensven LJLD (2010). Antibacterial effects of the essential oils of commonly consumed medicinal herbs using an in vitro model. Molecules 15:7532-7546.

Stanojević LjP, Marjanović-Balaban ŽR, Kalaba VD, Stanojević JS, Cvetković DJ, Cakić MD (2017). Chemical composition, antioxidant and antimicrobial activity of basil (Ocimum basilicum L.) essential oil. Journal of Essential Oil Bearing Plants 20(6):1557-1569.

Stefan M, Zamfirache MM, Padurariu C, Trută E, Gostin I (2013). The composition and antibacterial activity of essential oils in three Ocimum species growing in Romania. Central European Journal of Biology 8(6):600-608.

Taie HAA, Salama ZAER, Radwan S (2010). Potential activity of basil plants as a source of antioxidants and anticancer agents as affected by organic and bio-organic fertilization. Notulae Botanicae Horti Agrobotanici Cluj-Napoca38(1):119-127.

Varga F, Carović-Stanko K, Ristić M, Grdiša M, Liber Z, Šatović Z (2017). Morphological and biochemical intraspecific characterization of Ocimum basilicum L. Industrial Crops and Products 109:611-618.

Wesołowska A, Kosecka D, Jadczak D (2012). Essential oil composition of three sweet basil (Ocimum basilicum) cultivars. Herba Polonica 58(2):516.

Yugoslavian Pharmacopoeia (1984). Yugoslavian Pharmacopoeia, 4th ed. National Institute of Health Protection. Belgrade pp 126-127. 